\title{
GERMINATION TRAITS OF ADRIATIC LIZARD ORCHID (HIMANTOGLOSSUM ADRIATICUM) IN HUNGARY
}

\author{
GILIÁN, L. D. ${ }^{1,2^{*}}$ - BÓDIS, J. ${ }^{1}$ - EsZÉKI, E. ${ }^{3}$ - ILlYÉS, Z. ${ }^{4}$ - BIRÓ, É. ${ }^{1}-$ NAGY, J. GY. ${ }^{2}$ \\ ${ }^{1}$ Department of Plant Sciences and Biotechnology, Georgikon Faculty, University of Pannonia \\ H-8360 Keszthely, Festetics u. 7., Hungary \\ (phone: +36-83-545-095; fax: +36-83-545-058) \\ ${ }^{2}$ Doctoral School of Biological Sciences, Institute of Botany and Ecophysiology \\ Szent István University \\ H-2100 Gödöllö, Páter Károly utca 1., Hungary \\ (phone: +36-28-522-000; fax: +36-28/410-804) \\ ${ }^{3}$ Botanical Garden of Eötvös Loránd University \\ H-1083 Budapest, Illés u. 25., Hungary \\ (phone: +36-1-210-1074; fax: +36-1-314-0535) \\ ${ }^{4}$ Mindszenty Ifjúsági Ház \\ H-8900 Zalaegerszeg-Botfa, Várberki u. 13., Hungary \\ (phone: +36-30-954-7755) \\ *Corresponding author \\ e-mail: lilla.gilian@gmail.com
}

(Received $10^{\text {th }}$ Oct 2017; accepted $5^{\text {th }}$ Feb 2018)

\begin{abstract}
The germination of the orchids is the most sensitive period of their life. In case of the extremely rare Himantoglossum adriaticum in Hungary, no such information has been published yet. Our aim is to present the results of the in situ and the ex situ germination of H. adriaticum seeds originate in West Hungary. There were 10-10 seed packets sowed 10-20 cm far-, and 3-3 as control $10 \mathrm{~m}$ away from the living mother plants on the natural habitats of Keszthelyi-hills and of Sümeg-Tapolca region. The success of germination was significantly higher close to the mother plant than in the control packets either 8 or 11 months after sowing on both places and was a bit better in Keszthely than on Sümeg-Tapolca region. Parallelly with it we sowed the seeds of same origin into six flasks, onto Fast medium in the orchid laboratory of Eötvös Loránd University's Botanical Garden in Budapest. During this ex situ germination, the first protocorm was appeared 9 months after sowing. The germination was outstanding only in one flask. Our results show, that the germination in the natural habitat was much higher than in vitro on the generally used artificial media.
\end{abstract}

Keywords: Orchidaceae, field research, in situ propagation, ex situ propagation, in vitro, micropropagation, flask, Fast-media

\section{Introduction}

Nowadays, because of the environment-forming activity of people, the number and the area of natural habitats are decreasing all over the world. As we face the sixth great extinction event in the history of life on earth (Canadell and Noble, 2001), an increasing attention is being paid to biodiversity conservation (Swarts and Dixon, 2009).

The family Orchidaceae, with its more than 25,000 species, is the largest in the plant kingdom (Mabberley, 1997; Cribb et al., 2003). One-third of the orchids are terrestrials, and yet almost half of the extinct embryophytes according to The World Conservation Union (IUCN, 1999) are terrestrial herbaceous perennials. Terrestrial orchids thus 
represent a life-form class likely to experience a greater extinction risk as a result of the multiplicity of threatening processes, particularly under current climatic change scenarios (Swarts and Dixon, 2009).

Fragmentation of habitats, removal of key species critical to the continued existence of ecosystems, increased susceptibility to fire threats, pollinator decline and introduction of feral animals are also documented to result in drastic losses in orchid populations and diversity (Sosa and Platas, 1998; Coates and Dixon, 2007). Historically, collection of wild orchids has threatened many species with extinction (Cribb et al., 2003). Koopowitz et al. (2003) described a 'golden age' of plant collecting from the mid-1800s until the onset of the First World War. As a consequence, many orchids are recognized as endangered and vulnerable species (Shirokov et al., 2016). Based on Molnár V. et al. (2015), pollination crisis has not affected Hungarian orchids yet (at least in terms of reproductive success).

In the case of terrestrial orchids, for example, range and abundance may be driven by factors pertaining to the underground and above-ground life history phases of species (Woolcock and Woolcock, 1984; Clements, 1988; Dixon, 1989). The first need, represented in the underground phase, is a mycorrhizal association with a fungal endophyte (Warcup, 1971; Ramsay et al., 1986; Rasmussen, 2002). The second is effective pollination/fertilization in the above-ground phase (Stoutamire, 1983; Roberts, 2003). The great taxonomic diversity of Orchidaceae is often attributed to specialization of these two requirements (Swarts and Dixon, 2009).

Despite the orchids worldwide dispersion and extreme plasticity, the majority of these species are of key conservation importance (Jacquemyn et al., 2005; Kull and Hutchings, 2006; Swarts and Dixon, 2009). Protecting orchids, first of all we have to ensure them their suitable habitats. The specialist species with small area are much more vulnerable of the rapidly changing environmental conditions, than the widespread, generalist species. Causes of their decline are complex, but - independently of the conservation status - the long-term persistence of plant populations in every case partly depends on seed production (Biró et al., 2014) and their viability. Based on these facts, it is necessary to explore the reproductive capacity (viability) and the possibility of propagation of these species.

As for the in situ germination researches, it has been about 20 years since seed packets were first employed successfully to explore orchid germination and seedling development (Rasmussen and Whigham, 1993; Masuhara and Katsuya, 1994; Van der Kinderen, 1995; Zelmer et al., 1996). Because orchid seeds are minute, the first life stages of seedlings previously defied observation, but now experimental sowing in the field constitutes a useful routine procedure for identifying germination requirements (Rasmussen et al., 2015). The germination of terrestrial orchids is the most sensitive period of their life, because of their seed structure and their mycorrhizal fungus relationships. Under natural conditions, seeds of most terrestrial orchid species will germinate only in association with a compatible mycorrhizal fungus (Warcup, 1981; Ramsay et al., 1986; Arditti et al., 1990). Due to limited food reserves, orchid seeds have a complete dependency on nutrients supplied by the mycorrhizal association during early germination and seedling establishment phases (Rasmussen, 1995), although some species may substitute or acquire new mycorrhizal associates depending upon plant maturity (Bidartondo and Read, 2008).

For some protected plants the artificial germination (ex situ, in vitro), the grow-up and the replantation to their natural habitat has become inevitable. As regards artificial 
seed germination, orchids can be classified into three categories (Arditti, 1967; 1979; Arditti and Ernst, 1984). Terrestrial, temperate zone orchids are more difficult to germinate asymbiotically (Arditti, 1982) than the tropical ones. By ex situ, in vitro germination, it is very important, that the core must be unripe on the plant when we collect the seeds, because the seeds are only sterile until the cores are closed (Fast, 1980). In this case, seeds can be used without disinfection (Richter, 1982). After sowing, the seeds get a cold treatment called "chilling time", because it increases the degree of germination (De Pauw and Remphrey, 1993). According to Miyoshi and Mii (1988) a 12-week-long chilling time seems the most effective for the seeds.

As for our target species, Himantoglossum adriaticum H. Baumann has a central submediterranean distribution, currently known to occur in Austria, BosniaHerzegovina, Croatia, Czech Republic, Hungary, Italy, Slovakia, Slovenia (Fig. 1). The Czech Republic is at the boarder of the distribution (Dostalova et al., 2011; Pecoraro et al., 2013; Rybka et al., 2005; Bernhardt, 2011). Red Data Books of many countries contains this species (Conti et al., 1997; Király, 2007; Maglocky and Feráková, 1993; Grulich, 2012). The conservation status of H. adriaticum is Critically Endangered in the Czech Republic and in Slovakia, Endangered in Austria and in Hungary, Vulnerable in Slovenia and Near Threatened in Croatia (Dostalova et al., 2011). Additionally, $H$. adriaticum is suffering ongoing population declines and is listed in the Annex II of Council Directive 92/43/EEC (the 'Habitats Directive').

The reproductive success of Himantoglossum adriaticum is generally low. The flowers have been observed to be pollinated by the following bee species: Andrena haemorrhoa, A. carbonaria, A. nigroaenea, A. potentillae, Apis mellifera (Claessens and Kleynen, 2011), Colletes similis (Vöth, 1990; Sulyok et al., 1998), Bombus spp. (Teschner, 1980), Osmia caerulescens, Lasioglossum (Evylaeus) morio, Lasioglossum (Evylaeus) lucidulum, Megachile melanopyga (Bódis, 2010). Previously published fruit set data varied between 4.5 and $44 \%$ in Austria (Vöth, 1990), and between 5.4\% and 23.3\% in Hungary (Bódis and Molnár, 2009).

In case of any germination traits of Himantoglossum adriaticum, there is no information has been published yet. Our aim is to present the peculiarity of germination of $H$. adriaticum, either in laboratory (ex situ, in vitro) or under field conditions (in situ).

\section{Materials and methods}

\section{Himantoglossum adriaticum}

The Himantoglossum adriaticum - called "Adriatic lizard orchid" - is an AdriaticMediterranean, in Hungary is a collin-submontane species (Bódis et al., 2011). The characteristic habitat of the species is full sun to mid-shade and dry calcareous substrates. It prefers poor grassland, banks, thickets, woodland edges and open woodlands, up to $1600 \mathrm{~m}$ of altitude above sea level (Delforge, 2006). It often occurs in secondary habitats such as road sides, vineyards and abandoned mines (Dostalova et al., 2011).

In Hungary it has known only 5 populations: in the Keszthely Hills, in the SümegTapolca Region, in the Bakony Hills, in the Köszeg Mountains and in the Sopron Mountains (Fig. 1). The decrease of the historically known presence of the species is 35\% (Bódis et al., 2011). 


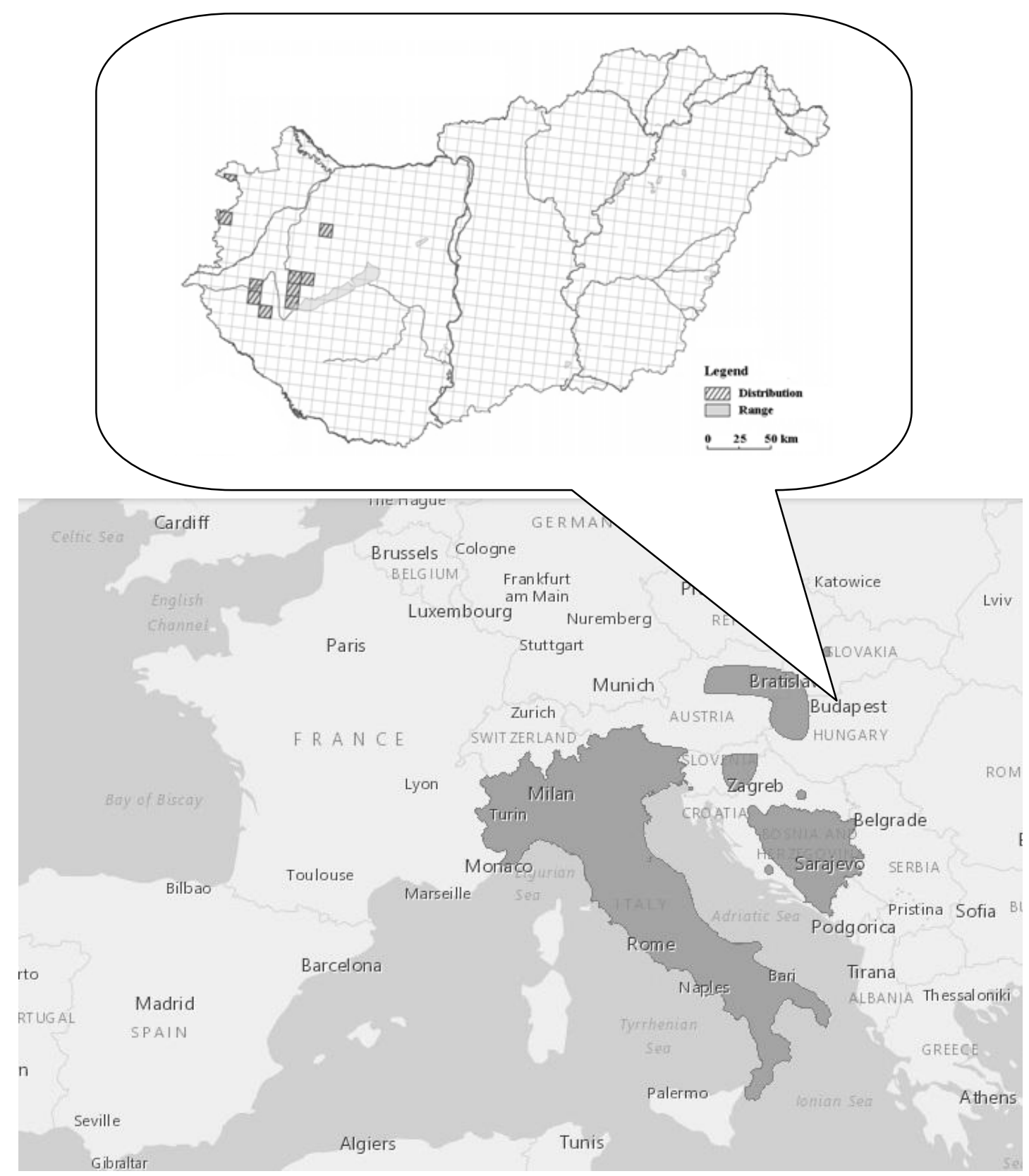

Figure 1. Map of the H. adriaticum populations in Europe, and highlighted in Hungary.

(Source: Europe map: The IUCN Red List of threatened species.

http://maps.iucnredlist.org/map.html?id=162219. Hungary map: Ministry of Agriculture,

Department of Nature Conservation, modified by the authors)

As for the relationship with mycorrhizal fungus, to get to know the mycorrhizal partner of this species, we need molecular taxonomic researches, for which roots or protocorms with initial shooting can be used. In Hungary, no one published experiments to get to know this. Based on Pecoraro et al. (2013) the international database (GenBank) contains, that they isolated Tulasnellaceae family from Italian $H$. adriaticum roots. We made an experiment to isolate the specific mycorrhizal fungal symbionts of the species in the study areas from protocorms, but those results have not been published yet. 


\section{Origin of seeds}

The $H$. adriaticum seeds were sown, originated from the Hungarian natural habitats (Keszthely Hills (K), Sümeg-Tapolca Region (ST), Bakony Mountains (B3, B13, B15) and Köszeg Mountains (KO)) and from the Croatian Istrian Peninsula (U), as a comparison. The capsules were ripe, dried, but they had not opened yet. The seeds were stored in a refrigerator for 15 days until use.

It was important to examine whether there is a significant difference between the germination of the seeds from different places. To do this we used the data of the variability testing, and we made variance analysis and significant difference calculations with Microsoft Excel 2013 computer program. In the variance analysis, the null hypothesis says that there is no significant difference between the habitats in the point of the germination averages. If the p-value $>0.05$ the null hypothesis can be accepted. The result was also confirmed with the significant difference calculations (SD5\%).

\section{Treatments and viability testing of seeds}

To get to know the theoretical viability of the seeds we used triphenyltetrazolium chloride (TTC). The more seeds are painted red, the higher viability rate they have. This method of Van Waes and Debergh (1986a, b) has become widely used for viability studies.

Before the painting with TTC, in order to crack the seed coat (because of the seeds of orchids are too small to scarify them with a scalpel to let the liquid reach the embrio) we tried 7 pretreatments: we let 100-100 seeds (from a mixture of the seeds from all habitats) in $0.5 \% ; 1 \% ; 2 \%$ and $4 \%$ sodium hypochlorite, in calcium hypochlorite, in sulphuric acid, and made a mechanical pericarp damage.

In the course of sodium-hypochlorite treatment, we let the seeds in $0.5 \% ; 1 \% ; 2 \%$ and $4 \%$ natrium-hypochlorite for $10 \mathrm{~min}$.

In the course of kalcium-hypochlorite treatment, we dissolved $10 \mathrm{~g}$ kalciumhypochlorite in $90 \mathrm{~cm}^{3}$ distilled water, and after 10 min we put the seeds into the mixture for $10 \mathrm{~min}$.

In the course of the acidic treatment, we put the seeds into $1 \%$ sodium-hypochlorite for $10 \mathrm{~min}$ and after that into $2 \% \mathrm{H}_{2} \mathrm{SO}_{4}$ for further $10 \mathrm{~min}$.

In the course of the mechanical pretreatment, we used quartz sand. We put the seeds and quartz sand into a test tube and shake them for $50 \mathrm{~s}$ on a test tube shaker. As we tested before, this time was enough to crack the seed coat without making destruction.

After the pretreatments we flush the seeds with distilled water for 3 times, then used the TTC method. We made a tincture from $1 \mathrm{~g}$ TTC and $100 \mathrm{~cm}^{3}$ distilled water, the seeds were put into this, and were laid in a full dark place for 5 days on $30^{\circ} \mathrm{C}$ temperature.

From these 7 kinds of pretreatments, we used that in our further experiment, which gave the best result. From all habitat we used 100-100 seeds in 10-10 test tube, and made the TTC viability-test after doing the best pretreatment on them. According to this we determined the viability of the seeds.

\section{Study area of the in situ germination}

The first study area of $H$. adriaticum was in Keszthely Hills, in western Hungary, at the boundary of the village Gyenesdiás and Keszthely town. The orchid population was found by I. Szabó, on both sides of the Pilikán-Szoroshad minor road, in dolomite 
grassland (Chrysopogono-Caricetum humilis), on the edge of the forest (Szabó, 1987). In the study area calciphilous oak woodland (dominated by Quercus petraea), shrub woodland and Black pine (Pinus nigra) plantation form a vegetation mosaic with dolomite grassland. Habitats are disturbed, the vegetation is degraded (owing to mainly human activities). H. adriaticum grows in the grassland near the road and on the edge of the expanding shrubs and trees (Origanetalia vulgaris) (Bódis and Molnár, 2009).

The second study area was the Sümeg-Tapolca Region. The largest Hungarian population is located next to the Sümeg and Nyirád roads, 4 and $2 \mathrm{~km}$ along (Sulyok et al., 1998). The specimens appear lonely or in small groups especially in the mowed road curbs (degraded Festuco-Brometea). Today the plants are located on the area of the Nyirád road, where grasslands and grassy shrubs were connected to the road fifty years ago. There are higher number of specimens in the "forest road" between Sümeg and Tapolca, especially in the yard of the Forester's House of Úrbér, on the lawn and in the road curbs. Many small vegetative individuals grow under Common Dogwood (Cornus sanguinea) and Blackthorn (Prunus spinosa) bushes. The flowering specimens are typically found in the shrub-grass meadows, and located along the road, in multifarious exposures and habitats. In addition to the fact that this is the largest population, diverse micro-habitats (which are independent from each other) facilitate the long-lasting survival (Bódis and Molnár, 2009).

As for the climate, the study areas are about $30 \mathrm{~km}$ away from each other, and both are in moderately warm-moderately dry climate. In the experimental areas, the annual average temperature is between 10 and $11^{\circ} \mathrm{C}$ and the annual precipitation amount is 650-750 mm.

2014 was a very rainy year, so the annual precipitation amount was above the average. The Walter-Lieth climate diagrams (Fig. $2 a$ and $b$ ) were made from the data were got online through MetNet and were drawn in RStudio program by us. They represent the climate of the two study areas in 2014. The diagrams show that the end of the winter, the spring and the summer, and the first two months in the autumn were subhumid and superhumid. In June, there was only few rain, so the germination could not be started. The extra rain in July, August and September were important for start up the germination in the seed baits.

The soil $\mathrm{pH}$ are 7.3-7.9 on the Hungarian habitats of $H$. adriaticum according to Molnár V. (2011).

\section{Research process of in situ germination}

Seed packets were constructed from 40x60mm rectangles of heat-sealed nylon mesh (Illyés, 2011) and about 300-500 seeds of $H$. adriaticum were placed in each. The pore size of the mesh $(85 \mu \mathrm{m}$ and $100 \mu \mathrm{m})$ was chosen to retain the seeds without impending fungal growth. The mesh was folded once and clipped into plastic glassless slide mounts (Rasmussen and Whigham, 1993).

Seed pockets were positioned vertically in top-soil (approx. depth $5 \mathrm{~cm}$ ) at 6-6 places in the Keszthely Hills and Sümeg-Tapolca Region in October 2013 (Table 1). 10-10 seed baits were positioned about $10-20 \mathrm{~cm}$ of a living plant and 6-6 seed baits about $10 \mathrm{~m}$ away of the living plants, as a control, where neither adult nor germinating plants were found. Seed baits were excavated at two occasions: in June 2014 and in September 2014. For the first time, we wanted to know whether the germination started. For the second time we can noticed various stages of germination (Figs. 3 and 4), so it was important to classify them by stages (Table 2). 

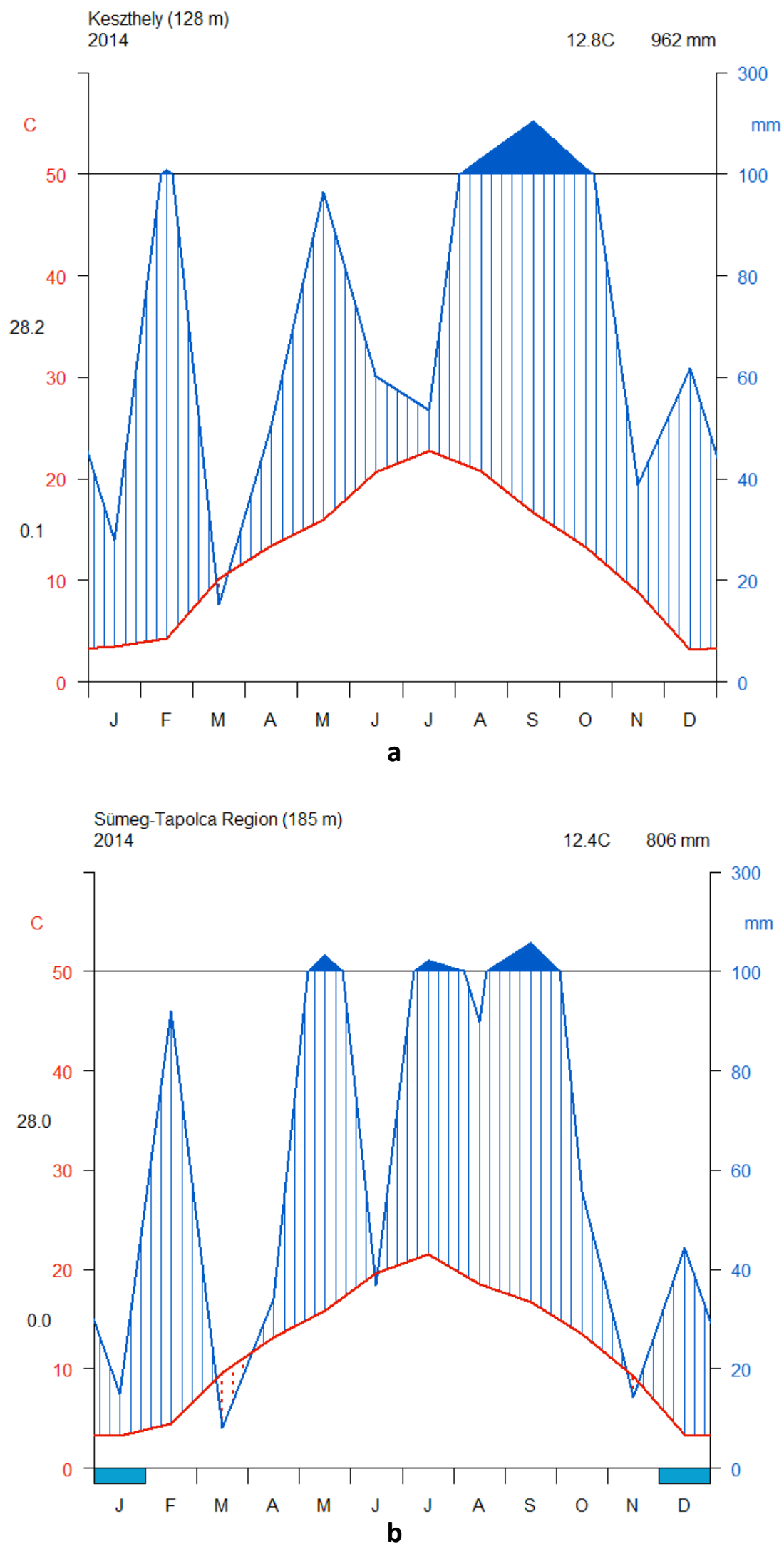

Figure 2. a: Walter-Lieth climate diagram of Keszthely for 2014. b: Walter-Lieth climate diagram of Sümeg-Tapolca Region for 2014 
Table 1. GPS datas of in situ seed baits that were placed into the field

\begin{tabular}{|c|c|c|c|}
\hline $\begin{array}{c}\text { Date of } \\
\text { placement }\end{array}$ & Place & $\begin{array}{l}\text { GPS coordinates of baits } \\
\text { placed next to a living plant }\end{array}$ & $\begin{array}{l}\text { GPS coordinates } \\
\text { of controll baits }\end{array}$ \\
\hline \multirow{6}{*}{ 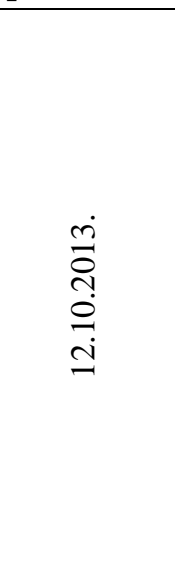 } & Keszthely 1 & $\begin{array}{l}46^{\circ} 47^{\prime} 33.1^{\prime \prime} \\
17^{\circ} 16^{\prime} 34.1^{\prime \prime}\end{array}$ & $\begin{array}{l}46^{\circ} 47^{\prime} 32.8^{\prime \prime} \\
17^{\circ} 16^{\prime} 34.1^{\prime \prime}\end{array}$ \\
\hline & Keszthely 2 & $\begin{array}{l}46^{\circ} 47^{\prime} 40.8^{\prime \prime} \\
17^{\circ} 16^{\prime} 38.8^{\prime \prime}\end{array}$ & $\begin{array}{l}46^{\circ} 47^{\prime} 40.8^{\prime \prime} \\
17^{\circ} 16^{\prime} 38.7^{\prime \prime}\end{array}$ \\
\hline & Keszthely 3 & $\begin{array}{l}46^{\circ} 47^{\prime} 43.1^{\prime \prime} \\
17^{\circ} 16^{\prime} 40.1^{\prime \prime}\end{array}$ & $\begin{array}{l}46^{\circ} 47^{\prime} 43.4^{\prime \prime} \\
17^{\circ} 16^{\prime} 39.4^{\prime \prime}\end{array}$ \\
\hline & Keszthely 4 & $\begin{array}{l}46^{\circ} 47^{\prime} 33.2^{\prime \prime} \\
17^{\circ} 16^{\prime} 36.4^{\prime \prime}\end{array}$ & $\begin{array}{l}46^{\circ} 47^{\prime} 33.0^{\prime \prime} \\
17^{\circ} 16^{\prime} 36.3^{\prime \prime}\end{array}$ \\
\hline & Keszthely 5 & $\begin{array}{l}46^{\circ} 47^{\prime} 53.3^{\prime \prime} \\
17^{\circ} 16^{\prime} 51.9^{\prime \prime}\end{array}$ & $\begin{array}{l}46^{\circ} 47^{\prime} 53.6^{\prime \prime} \\
17^{\circ} 16^{\prime} 52.4^{\prime \prime}\end{array}$ \\
\hline & Keszthely 6 & $\begin{array}{l}46^{\circ} 48^{\prime} 04.1^{\prime \prime} \\
17^{\circ} 16^{\prime} 57.5^{\prime \prime}\end{array}$ & $\begin{array}{l}46^{\circ} 48^{\prime} 04.0^{\prime \prime} \\
17^{\circ} 16^{\prime} 58.4^{\prime \prime}\end{array}$ \\
\hline \multirow{6}{*}{$\begin{array}{l}\stackrel{\dot{\theta}}{\circ} \\
\stackrel{\sim}{0} \\
\stackrel{0}{\leftrightarrows} \\
\dot{0}\end{array}$} & Sümeg-Tapolca 1 & $\begin{array}{l}46^{\circ} 57^{\prime} 28.8^{\prime \prime} \\
17^{\circ} 20^{\prime} 49.2^{\prime \prime}\end{array}$ & $\begin{array}{l}46^{\circ} 57^{\prime} 28.5^{\prime \prime} \\
17^{\circ} 20^{\prime} 50.3^{\prime \prime}\end{array}$ \\
\hline & Sümeg-Tapolca 2 & $\begin{array}{l}46^{\circ} 57^{\prime} 29.7^{\prime \prime} \\
17^{\circ} 20^{\prime} 49.4^{\prime \prime}\end{array}$ & $\begin{array}{l}46^{\circ} 57^{\prime} 29.5^{\prime \prime} \\
17^{\circ} 20^{\prime} 50.4^{\prime \prime}\end{array}$ \\
\hline & Sümeg-Tapolca 3 & $\begin{array}{l}46^{\circ} 57^{\prime} 25.4^{\prime \prime} \\
17^{\circ} 21^{\prime} 10.2^{\prime \prime}\end{array}$ & $\begin{array}{l}46^{\circ} 57^{\prime} 27.5^{\prime \prime} \\
17^{\circ} 21^{\prime} 09.7^{\prime \prime}\end{array}$ \\
\hline & Sümeg-Tapolca 4 & $\begin{array}{l}46^{\circ} 57^{\prime} 22.7^{\prime \prime} \\
17^{\circ} 21^{\prime} 16.4^{\prime \prime}\end{array}$ & $\begin{array}{l}46^{\circ} 57^{\prime} 22.7^{\prime \prime} \\
17^{\circ} 21^{\prime} 16.8^{\prime \prime}\end{array}$ \\
\hline & Sümeg-Tapolca 5 & $\begin{array}{l}46^{\circ} 57^{\prime} 08.8^{\prime \prime} \\
17^{\circ} 21^{\prime} 58.1^{\prime \prime}\end{array}$ & $\begin{array}{l}46^{\circ} 57^{\prime} 08.9^{\prime \prime} \\
17^{\circ} 21^{\prime} 57.7^{\prime \prime}\end{array}$ \\
\hline & Sümeg-Tapolca 6 & $\begin{array}{l}46^{\circ} 56^{\prime} 43.5^{\prime \prime} \\
17^{\circ} 22^{\prime} 24.1^{\prime \prime}\end{array}$ & $\begin{array}{l}46^{\circ} 56^{\prime} 43.4^{\prime \prime} \\
17^{\circ} 22^{\prime} 23.8^{\prime \prime}\end{array}$ \\
\hline
\end{tabular}

Table 2. Protocorms classified by stages at in situ germination

\begin{tabular}{c|c}
\hline Stages & Short explanation \\
\hline 0. & The protocorm visibly swollen in the seed coat, but it still did not break it through \\
1. & The protocorm broke through the seed coat but the seed coat is still visible on it \\
2. & The seed coat is no more visible and we can see the rhizoid hairs \\
3. & The size of the protocorms is few mm and they are perceptible to the eye and we can see the \\
shoot initiation
\end{tabular}

\section{Research process of ex situ (in vitro) germination}

The ex situ germination was carried out in the laboratory of the Eötvös Loránd University's Botanical Garden on September 2013. We made the pretreatment, which was equivalence also the necessary sterilization, and the sowing in laminar flow with sterile instruments. The seeds were sown on modified "Fast" media, because it gives the best germination results of Hungarian terrestrial orchids (R. Eszéki, Szendrák, 1992). We summarized the recipe of modified "Fast" media in Table 3. 


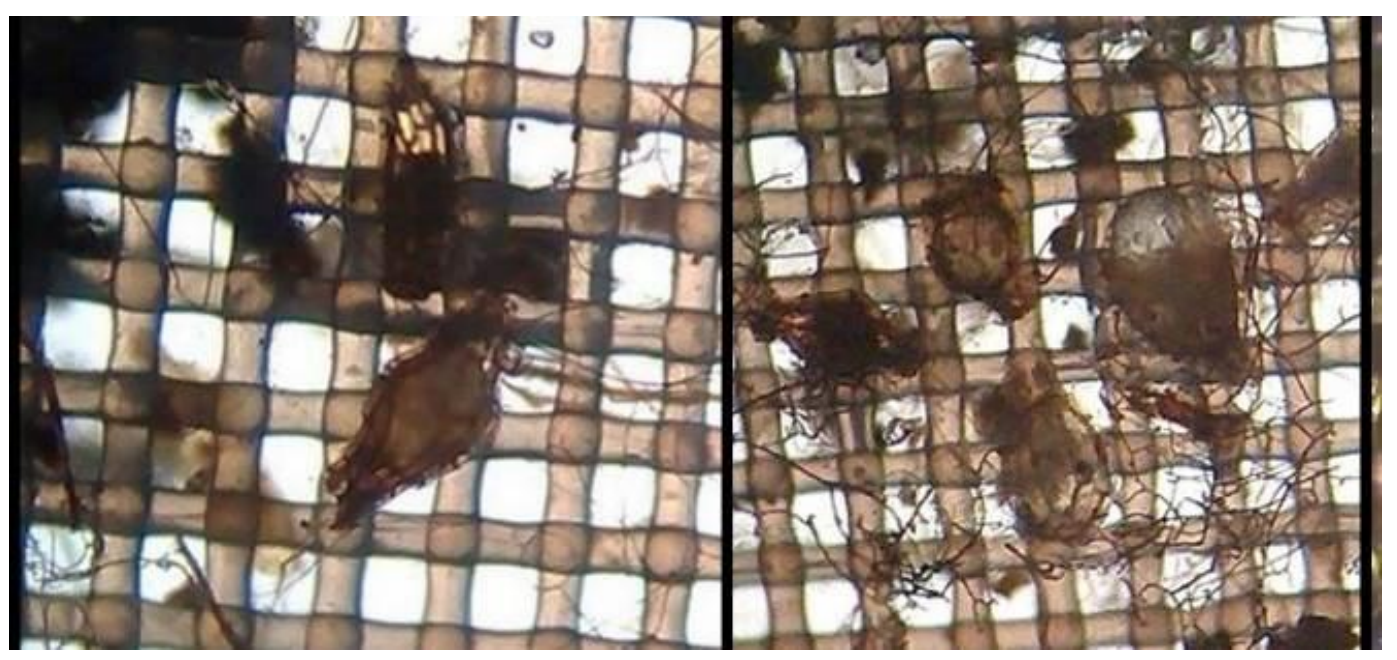

Figure 3. In situ stage 0 and stage 1

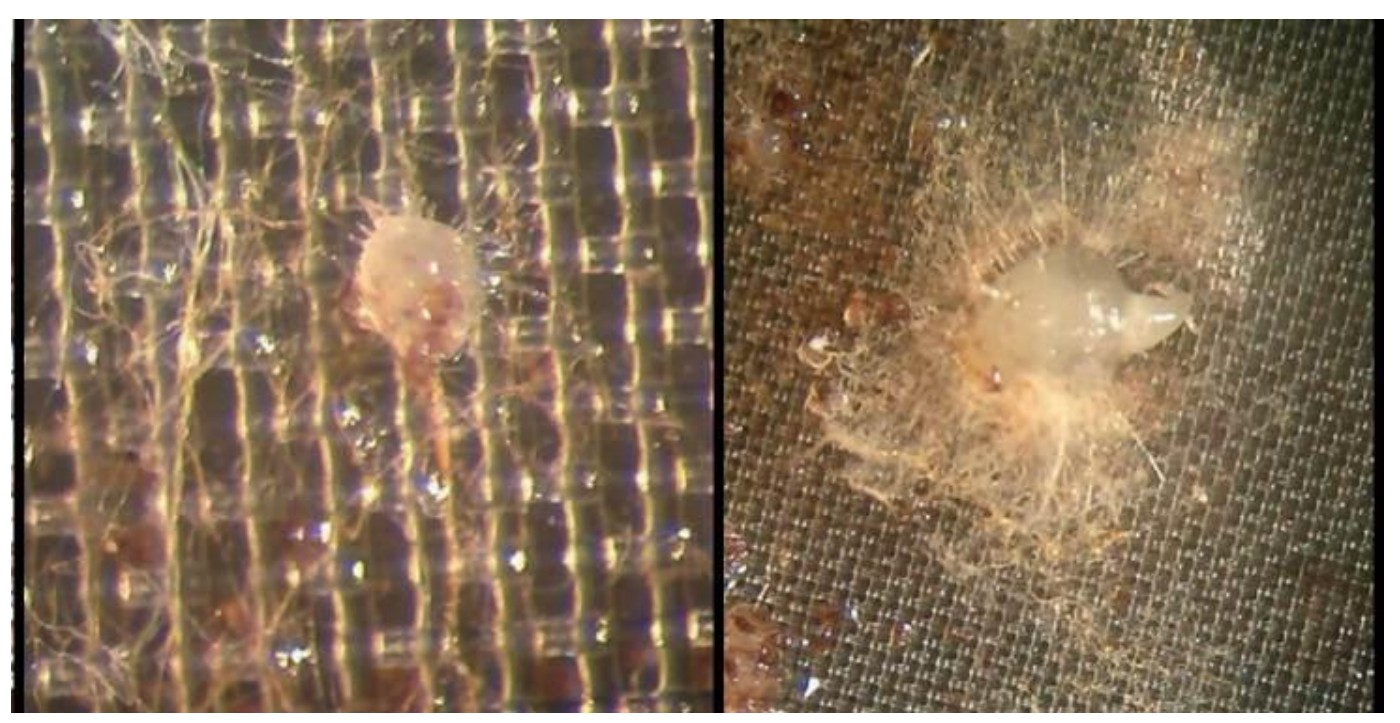

Figure 4. In situ stage 2 and stage 3

Table 3. The recipe of modified "Fast" media

\begin{tabular}{c|c}
\hline Ingredients (1200ml) & Quantity \\
\hline $\mathrm{Ph}: 5.5$ & $100 \mathrm{mg}$ \\
$\mathrm{Ca}\left(\mathrm{NO}_{3}\right)_{2} \mathrm{X}_{4} \mathrm{H} \mathrm{H}_{2} \mathrm{O}$ & $200 \mathrm{mg}$ \\
$\mathrm{NH}_{4} \mathrm{NO}_{3}$ & $100 \mathrm{mg}$ \\
$\mathrm{KH}_{2} \mathrm{PO}_{4}$ & $200 \mathrm{mg}$ \\
$\mathrm{KCl}$ & $100 \mathrm{mg}$ \\
$\mathrm{MgSO}_{4} \mathrm{X} 7 \mathrm{H}_{2} \mathrm{O}$ & $30 \mathrm{mg}$ \\
$\mathrm{Fe}^{-c h e l a t e}$ & $1 \mathrm{ml}$ \\
$\mathrm{Heller-mikro}$ & $14 \mathrm{~g}$ \\
Saccharose & $6 \mathrm{~g}$ \\
Fructose & $1 \mathrm{~g}$ \\
Pepton & $250 \mathrm{mg}$ \\
Polivitaplex & $100 \mathrm{mg}$ \\
Inozit & $10 \mathrm{~g}$ \\
\hline
\end{tabular}


Before sowing, we made a pretreatment: we dissolved $10 \mathrm{~g}$ kalcium-hypoclorite in $90 \mathrm{~cm}^{3}$ distilled water, then gave some drop of Tween to the mixture and let it clear. Then we put the seeds into test tubes and pour the filtrate on them for $10 \mathrm{~min}$. After that, in the sterile box, we sowed the seeds from the test tubes onto the modified Fast media with a sterile scalpel. We covered the flasks with foil three times, then covered them with aluminium foil. The firs week was an incubation time, we monitored if it stayed sterile or not. After the incubation time we put the flasks into fridge $\left(4^{\circ} \mathrm{C}\right)$ for 3 months. Then, we put them into a dark box on room temperature $\left(24^{\circ} \mathrm{C}\right)$ until the first protocorms appeared. After the first protocorms appearance we checked the flasks monthly.

\section{Results}

\section{Viability testing}

In the variance analysis, the p-value was higher than 0.05 (Table 4), so the null hypothesis could be accepted.

Table 4. Results of the variance analysis

\begin{tabular}{c|c|c|c|c|c|c}
\hline \multicolumn{7}{c}{ VARIANCE ANALYSIS } \\
\hline Source of variation & $S S$ & $d f$ & $M S$ & $F$ & p-value & F crit. \\
\hline Between groups & 115 & 3 & 38.33333 & 1.721987 & $\mathbf{0 . 1 7 9 8 1 2}$ & 2.866266 \\
Within groups & 801.4 & 36 & 22.26111 & & & \\
Total & 916.4 & 39 & & & & \\
\hline
\end{tabular}

Based on the results, we can state that there is no significant difference between the seed's average of germination, so it does not cause any problems during the experiments that the seeds originated from different habitats. Thus, the seeds can be used separately from each habitat, or a mixture can be made from the seeds of all of the habitats, it has no effect on the results.

From the pretreatments the mechanical pericarp fracture gave the best results (Table 5), so we made the testing with this method. The germination of the seeds after the ten times repetitions of viability testing was $17.7 \%$ on average.

\section{In situ germination}

We summarized the results of the in situ germination 8 and 11 month after sowing.

The in situ germination was $0.094 \%$ in the Keszthely Hills 8 months after sowing. $10-20 \mathrm{~cm}$ from the living plants this rate increased to $0.1 \%$. The germination in the control packets was $0.08 \%$. 11 months after sowing, the germination increased to $42 \%$, included the "Stage 0" protocorms too. Next to the living plants, the germination was $50.3 \%$. In the control packets this value was $19.4 \%$.

On the Sümeg-Tapolca Region, the in situ germination was $0.11 \% 8$ months after sowing. $10-20 \mathrm{~cm}$ from the living plants the germination was $0.13 \%$. In the control packets we have not found any protocorms. 11 months after sowing, the germination of the seeds was $34.7 \%$. Next to the living plants, this value increased to $39.9 \%$. The germination was $3.5 \%$ in the control packets. 
Table 5. Percentage of seeds were painted red by TTC

\begin{tabular}{ll|c}
\hline & \multicolumn{1}{c|}{ Pretreatments, length of time } & Seeds were painted red (\%) \\
\hline 1. & Sodium-hypochlorite, $10 \mathrm{~min}, 0.5 \%$ & 21 \\
2. & Sodium-hypochlorite, $10 \mathrm{~min}, 1 \%$ & 17.5 \\
3. & Sodium-hypochlorite, $10 \mathrm{~min}, 2 \%$ & 17 \\
4. & Sodium-hypochlorite, $10 \mathrm{~min}, 4 \%$ & 19 \\
5. & $10 \mathrm{~g}$ sodium-hypochlorite/ $90 \mathrm{~cm}^{3} \mathrm{H}_{2} \mathrm{O}, 10 \mathrm{~min}$ & 16 \\
6. & $1 \%$ sodium-hypochlorite, $10 \mathrm{~min}$, after then $2 \% \mathrm{H}_{2} \mathrm{SO}_{4}, 10 \mathrm{~min}$ & 13 \\
\hline 7. & Mechanical pericarp fracture $50 \mathrm{~s}$ & 35 \\
\hline
\end{tabular}

\section{Ex situ germination}

After the sowing, none of the flasks became infected. During the ex situ germination, the first protocorm was appeared 9 months after sowing. The germination was outstanding only in one flask (from the Bakony mts.), marked "B13". The germination of this flask was $1.3 \% 13$ months after sowing. In the other flasks, there was maximum 1-2 protocorms. After the first protocorm's appearance, we checked the flasks monthly. We summarized these results in Table 6. In October 2014, 13 months after sowing, we checked every flask and kept a record of the protocorms and seedlings according to stages we found in them (Figs. 5, 6 and 7). In Table 7, a short explanation can be found about the protocorms and seedlings by stages. The results of protocorms and seedlings were found in the flasks 13 months after sowing are summarized in Table 8.

After the first protocorm's appearance, we put the flasks onto natural light. Newer protocorms appeared which started to grow faster than the protocorms appeared in the dark. The new protocorms became larger and more powerful in a month.

18 months after sowing, the protocorms appeared on natural light have grown to a powerful 6-11-cm big seedling.

Table 6. Protocorms founded in flasks monthly (B - Bakony mts, ST - Sümeg-Tapolca Region, KO - Köszeg mts, U-Istrian Peninsula)

\begin{tabular}{c|c|c|c|c|c|c}
\hline Time of checking & B3 & B13 & B15 & ST & KO & U \\
\hline 2014.06 .04 & 2 & 30 & 0 & 1 & 0 & 0 \\
2014.07 .11 & 2 & 46 & 0 & 1 & 0 & 0 \\
2014.08 .11 & 3 & 74 & 2 & 2 & 0 & 2 \\
2014.09 .09 & 3 & 87 & 1 & 2 & 0 & 3 \\
2014.10 .04 & 3 & 104 & 1 & 2 & 1 & 3 \\
\hline
\end{tabular}

Table 7. Protocorms and seedlings by stages, short explanation

\begin{tabular}{c|c}
\hline Stages & Short explanation \\
\hline Stage 1. & The white protocorm with rhizoid hair appears \\
Stage 2. & The shoot initiation appears on the white protocorm \\
Stage 3. & $\begin{array}{c}\text { One-leaved-staged green seedling appears on the white } \\
\text { protokorm. }<1 \mathrm{~cm}\end{array}$ \\
Stage 4. & Green, two-leaved-staged seedling. $\sim \mathrm{cm}$ \\
Stage 5. & Green, two-leaved-staged seedling. $\sim \mathrm{cm}$ \\
Stage 6. & Green, two-leaved-staged seedling. $\sim 3 \mathrm{~cm}$ \\
Stage 7. & Green, two-leaved-staged seedling. $>5 \mathrm{~cm}$ \\
\hline
\end{tabular}


Table 8. Protocorms and seedlings by stages in flasks, 13 months after sowing ( $S=$ Seeds were sown onto the media in one flask, St $=$ Stage, $T=$ total, $G R=$ germination rate)

\begin{tabular}{c|c|c|c|c|c|c|c|c|c|c}
\hline \multirow{2}{*}{$\begin{array}{c}\text { Flask } \\
\text { code }\end{array}$} & \multirow{2}{*}{$\begin{array}{c}\text { S } \\
\text { (pcs) }\end{array}$} & $\begin{array}{c}\text { St 1 } \\
\text { (pcs) }\end{array}$ & $\begin{array}{c}\text { St 2 } \\
(\mathbf{p c s})\end{array}$ & $\begin{array}{c}\text { St 3 } \\
(\mathbf{p c s})\end{array}$ & $\begin{array}{c}\text { St 4 } \\
(\mathbf{p c s})\end{array}$ & $\begin{array}{c}\text { St 5 } \\
(\mathbf{p c s})\end{array}$ & $\begin{array}{c}\text { St 6 } \\
(\mathbf{p c s})\end{array}$ & $\begin{array}{c}\text { St 7 } \\
(\mathbf{p c s})\end{array}$ & $\begin{array}{c}\text { T } \\
(\mathbf{p c s})\end{array}$ & $\begin{array}{c}\text { GR } \\
(\%)\end{array}$ \\
\hline B3 & 9216 & 0 & 0 & 0 & 0 & 1 & 1 & 1 & 3 & 0.03 \\
B13 & 8100 & 10 & 8 & 10 & 20 & 22 & 24 & 10 & 104 & 1.3 \\
B15 & 12224 & 1 & 0 & 0 & 0 & 0 & 0 & 0 & 1 & 0.008 \\
ST & 9960 & 0 & 1 & 0 & 1 & 0 & 0 & 0 & 2 & 0.02 \\
KO & 11300 & 0 & 1 & 0 & 0 & 0 & 0 & 0 & 1 & 0.009 \\
U & 10184 & 0 & 0 & 3 & 0 & 0 & 0 & 0 & 3 & 0.03 \\
\hline
\end{tabular}

\section{Discussion}

During the viability test, after the pretreatments, if the TTC gets into the seed coat, it colours the seeds to red. This is only a theoretical ratio, it is not suitable to determine the true germination rate. This result is not comparable with the results of the in situ germination rate, because the microflora in the soil is like to digest the outer husk down from the embryo. We cannot reach artificially as good results as it can with this natural way of "pretreatment". The theoretical germination rate we get during viability tests is smaller $(17.7 \%$ on average) than the measured germination rates $(42 \%)$ on their natural habitat (in situ), but much higher, than the ex situ germination in flasks $(0.18 \%)$. So, the seed's reddish discoloration (formazan formation) during the TTC test was not necessarily a warrant for the seeds high germination.
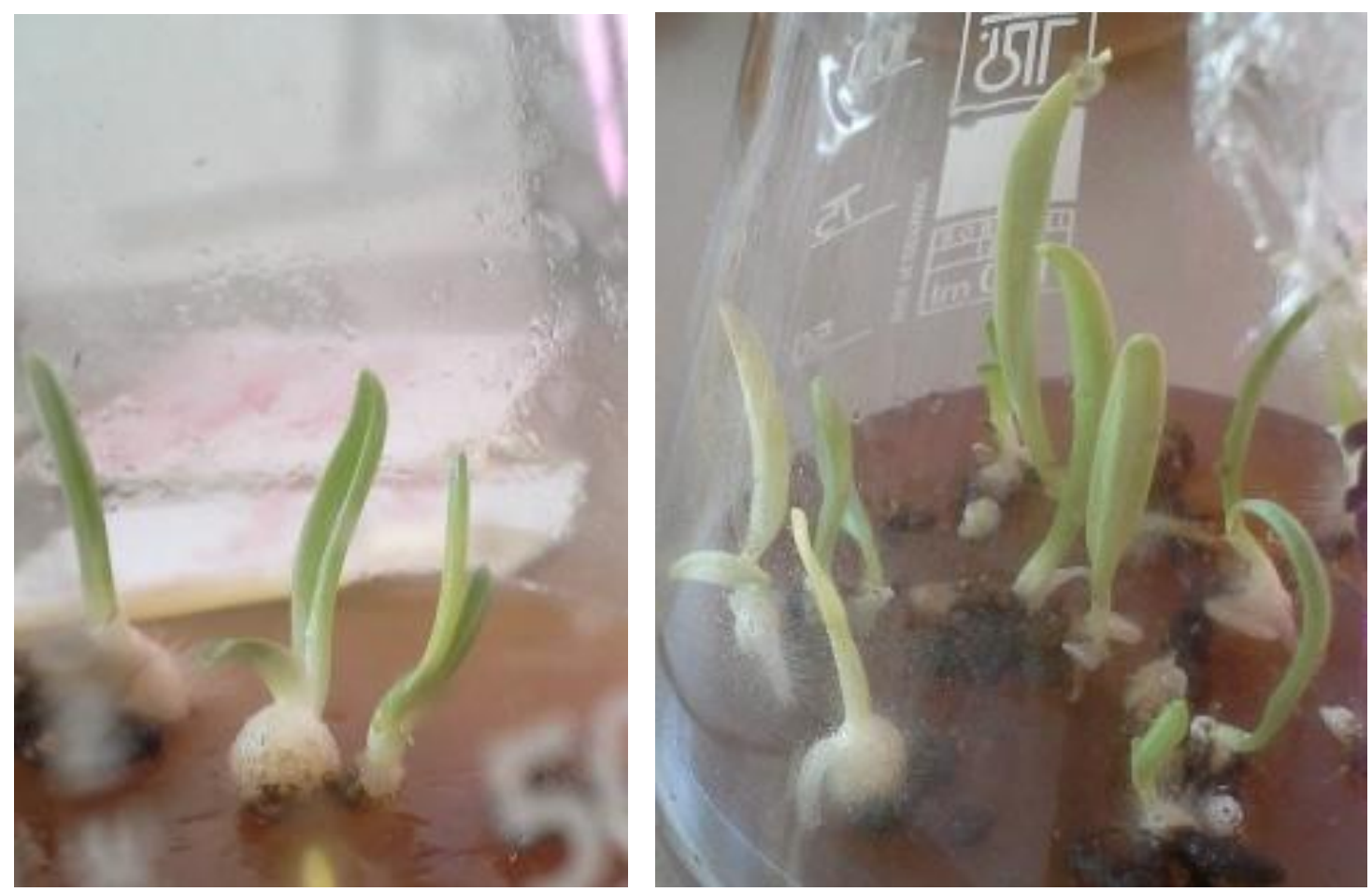

Figure 5. Ex situ stage 1 and stage 2-3 

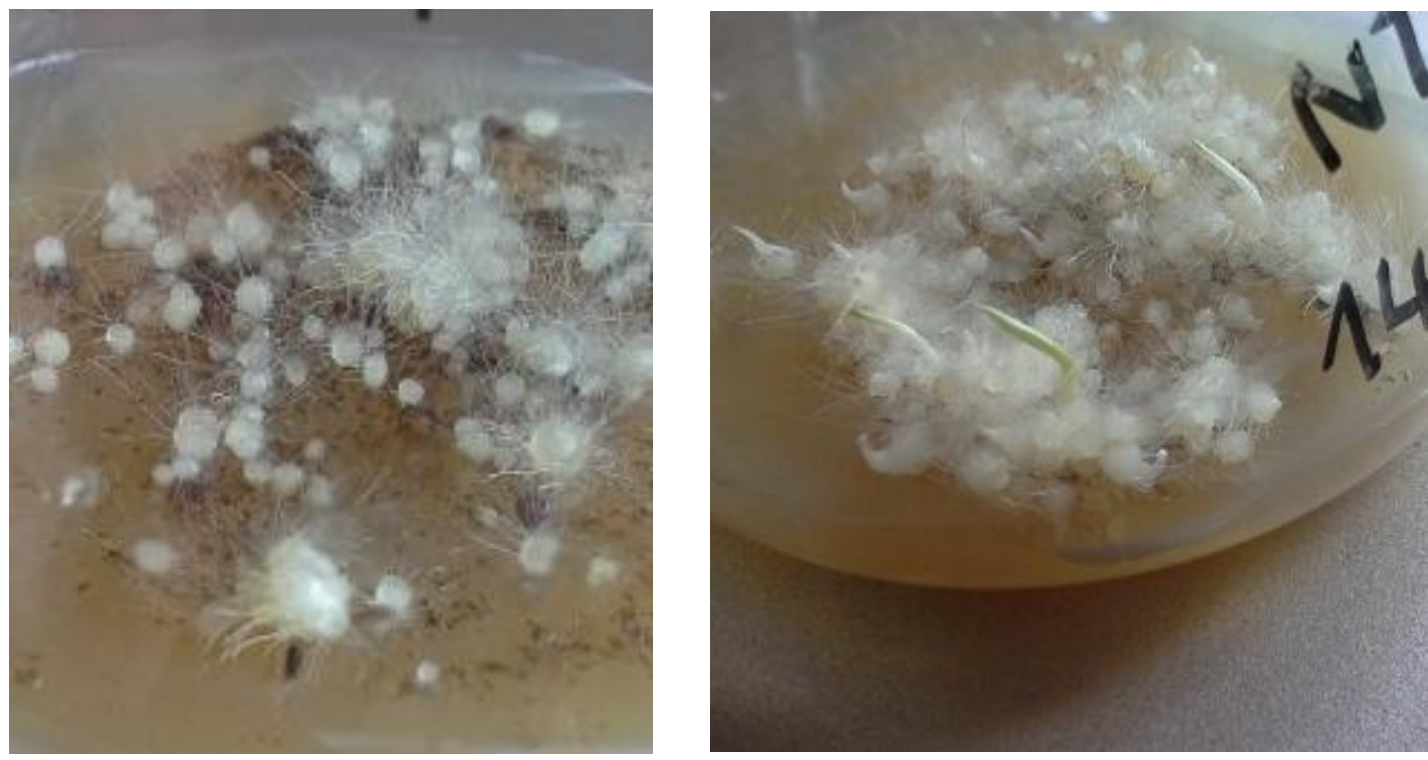

Figure 6. Ex situ stage 4 and stages 5-6

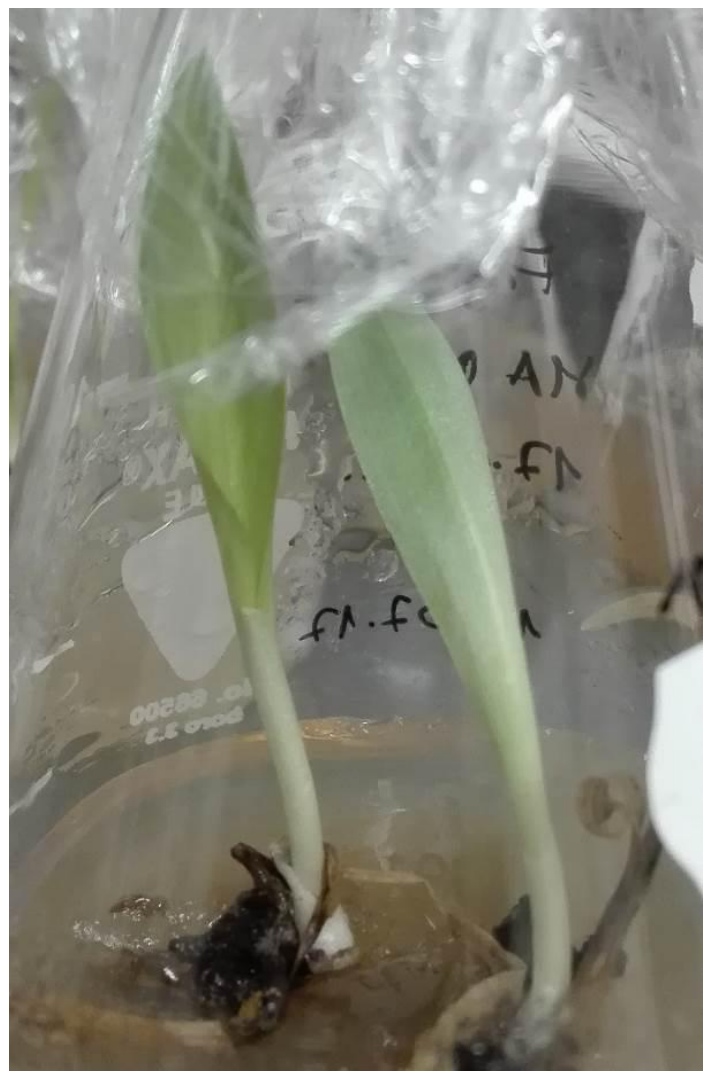

Figure 7. Ex situ stage 7

If we see the in situ germination's results, it is perceptible, that between the sown in October and the excavation in June, the 8 months were not enough for most of the seeds to germinate, but between the two excavations in June and September, in that 3 months the germination was started. 
If we see the in situ germination's results, it is perceptible, that between the sown in October and the excavation in June, the 8 months were not enough for most of the seeds to germinate, but between the two excavations in June and September, in that 3 months the germination was started.

Consequently, the seeds needed 8-11 months after sowing to start to germinate on their natural habitats. It is very important to note, that into this result, we also calculated the protocorms in stage 0 and 1, so the "near-germination" seeds too. In these stages, the seeds do not need symbiotic fungal relationships, so these are not "real" protocorms, but very important data to see, how many seeds are viable, how many has the option, that meeting with the right fungi, the shoot initiation starts to grow, and it became a real seedling.

According to our microscopic observation, the symbiosis of the fungi and the orchid protocorm starts between the first and second stage: after when the white protocorm with rhizoid hair appears but before when the shoot initiation appears on this white protocorm.

Comparing the in situ and the ex situ germination, the seeds of $H$. adriaticum started to germinate 9-11 months after sowing in a high volume, so the seeds were in a resting period till then, but kept their ability of germination.

\section{Conclusion}

Our research shows, that the germination rate of $H$. adriaticum seeds is reassuringly high in its natural habitats, so this phase of the plants life is probably not a key element of the species endangerment. Meeting with the fungal partner, which pushes the germination on and starts the embryo's growth, is a much rarer event. Our next step is to determine the specific mycorrhizal fungal symbionts of the species in the Hungarian habitats both from protocorms and roots, so that we could compare the results. We can declare that the seeds from the Hungarian habitats are able to germinate artificially. According to the in vitro germination, the species can be germinated on modified "Fast" media ( $\mathrm{pH}$ 5.5). Based on Molnár V. (2011) about the soil $\mathrm{pH}$ on the natural habitats of the species, we think that $H$. adriaticum seeds could achieve higher germination rates with higher media $\mathrm{pH}$. So, the next step in our research will be to measure the soil $\mathrm{pH}$ on their natural habitats, and saw the seeds onto media with multifarious $\mathrm{pH}$, from which we can ascertain that our speculation is true or not.

Acknowledgements. Thanks to Mrs. Nóra Baranyai for the help in the statistical analysis. Thank you for referees for the detailed and helpful comments, remarks and suggestions they gave us.

\section{REFERENCES}

[1] Arditti, J. (1967): Factors affecting the germination of orchid seed. - Bot. Rev. 33: 1-97.

[2] Arditti, J. (1979): Aspects of the physiology of orchids. - Advances Bot. Res. 7: 241-665.

[3] Arditti, J. (1982): Orchid Seed Germination and Seedling Culture - A Manual. - In: Arditti, J. (ed.): Orchid Biology: Reviews and Perspectives, III. Cornell University Press, Ithaca.

[4] Arditti, J., Ernst, R. (1984): Physiology of Germinating Orchid Seeds. - In: Arditti, J. (ed.) Orchid Biology: Reviews and Perspectives, III. Cornell University Press, Ithaca. 
[5] Arditti J., Ernst, R., Wing Yam, T., Glabe, C. (1990): The contribution of orchid mycorrhizal fungi to seed germination: a speculative review. - Lindleyana 5: 249-255.

[6] Bernhardt, K. G. (2011): Himantoglossum adriaticum. - IUCN 2013. IUCN Red List of Threatened Species. Version 2013.2. www.iucnredlist.org.

[7] Bidartondo, M. I., Read, D. J. (2008): Fungal specificity bottlenecks during orchid germination and development. - Mol. Ecol. Aug. 17(16): 3707-16.

[8] Biró, É., Bódis, J., Nagy, T., Tökölyi, T., Molnár V., A. (2014): Honeybee (Apis mellifera) mediated increased reproductive success of a rare deceptive orchid. - Applied Ecology and Environmental Research 13(1): 181-192.

[9] Bódis, J. (2010): Himantoglossum adriaticum populációk dinamikája: demográfiai és életmenet jellemzők [Variaton of demography and life history characteristics in Himantoglossum adriaticum populations] (in Hungarian). - $\mathrm{PhD}$ Thesis. Biológiai Doktoriskola, Pécsi Tudományegyetem, Pécs.

[10] Bódis, J., Molnár, E. (2009): Long-term monitoring of Himantoglossum adriaticum H. Baumann population in Keszthely Hills, Hungary. - Natura Somogyiensis 15: 27-40.

[11] Bódis, J., Sramkó, G., Óvári, M., Molnár V., A. (2011): The Lifestyle and Stock Dynamics of European Orchids. - In: Molnár V., A. (ed.) Atlas of Orchids in Hungary. Kossuth Kiadó, Budapest.

[12] Canadell, J., Noble, I. (2001): Challenges of a changing earth. - Trends in Ecology and Evolution 16: 664-666.

[13] Claessens, J., Kleynen, J. (2011): The flower of the European orchid. Form and function. - Claessens \& Kleynen, Geuelle.

[14] Clements, M. A. (1988): Orchid mycorrhizal associations. - Lindleyana 3: 73-86

[15] Coates, D. J., Dixon K. W. (2007): Current perspectives in plant conservation biology. Australian Journal of Botany 55: 187-193.

[16] Conti, F., Manzi, A., Pedrotti F. (1997): Liste rosse regionali delle piante d'Italia. WWF/Società Botanica Italiana, Camerino.

[17] Cribb, P. J., Kell, S. P., Dixon, K. W., Barrett, R. L. (2003): Orchid Conservation: A Global Perspective. - In: Dixon, K. W., Kell, S. P., Barrett, R. L., Cribb, P. J. (eds.) Orchid Conservation. Natural History Publications, Kota Kinabalu.

[18] De Pauw, M. A., Remphrey, W. R. (1993): In vitro germination of three Cypripedium species in relation to time of seed collection, media, and cold treatment. - Canadian Journal of Botany 71: 879-885.

[19] Delforge, P. (2006): Orchids of Europe, North Africa and Middle East. - A\&C Black, London.

[20] Dixon, K. W. (1989): Seed Propagation of Ground Orchids. - In: Dixon, K. W., Buirchell, B. J., Collins, M. J. (eds.) Orchids of Western Australia. 2nd edn. Native Orchid Study and Conservation Group Inc, Victoria Park.

[21] Dostalova, A., Montagnani, C., Hodálová, I., Jogan, N., Király, G., Ferakova, V., Bernhardt, K. G. (2011): Himantoglossum adriaticum. - The IUCN Red List of Threatened Species 2011: e.T162219A5559772.

[22] Fast, G. (1980): Vermehrung und Anzucht. - In: Fast, G. (ed.) Orchideenkultur, Botonische Grundlagen, Kulturverfahren, Pflanzenbeschreibungen. Eugen Ulmer Verlag, Stuttgart.

[23] Grulich, V. (2012): Red List of vascular plants of the Czech Republic. - Preslia 84: 631645.

[24] Illyés, Z. (2011): Orchid Type Mycorrhiza. - In: Molnár V., A. (ed.) Atlas of Orchids in Hungary. - Kossuth Kiadó, Budapest.

[25] IUCN (1999): IUCN guidelines for the prevention of biodiversity loss due to biological invasion. - Species 31-32: 28-42.

[26] Jacquemyn, H., Brys, R., Hermy, M., Willems, J. H. (2005): Does nectar reward affect rarity and extinction probabilities of orchid species? An assessment using historical records from Belgium and the Netherlands. - Biological Conservation 121(2): 257-263. 
[27] Király, G. (ed.) (2007): Red list of the vascular flora of Hungary (in Hungarian). - Private edition, Sopron.

[28] Koopowitz, H., Lavarack, P. S., Dixon, K. W. (2003): The Nature of Threats to Orchid Conservation. - In: Dixon, K. W., Kell, S. P., Barrett, R. L, Cribb, P. J. (eds.) Orchid Conservation. Natural History Publications, Kota Kinabalu.

[29] Kull, T., Hutchings, M. J. (2006): A comparative analysis of decline in the distribution ranges of orchid species in Estonia and the United Kingdom. - Biological Conservation 129: 31-39.

[30] Mabberley, D. J. (1997): The Plant Book. - Cambridge University Press, Cambridge.

[31] Maglocky, S., Feráková, V. (1993): Red list of ferns and flowering plants (Pteridophyta and Spermatophyta) of the flora of Slovakia (the second draft). - Biologia 48(4): 361385.

[32] Masuhara, G, Katsuya, K. (1994): In situ and in vitro specificity between Rhizoctonia spp. and Spiranthes sinensis (Persoon) Ames var. amoena (M.Bieberstein) Hara. - New Phytologist 127: 711-718.

[33] Miyoshi, K., Mii, M. (1988): Ultrasonic treatment for enhancing seed germination of terrestrial orchid, Calanthe discolor, in asymbiotic culture. - Scientia Horticulturae 35: 127-130.

[34] Molnár V., A. (ed.) (2011): Atlas of Orchids in Hungary. - Kossuth Kiadó, Budapest.

[35] Molnár V., A., Löki, V., Takács, A., Schmidt, J., Tökölyi, J., Bódis, J., Sramkó, G. (2015): The reproductive success of Hungarian orchids has not changed in the last century. - Applied Ecology and Environmental Research 13(4): 1097-1108.

[36] Pecoraro, L., Girlanda, M., Kull, T., Perini, C., Perotto, S. (2013): Fungi from the roots of the terrestrial photosynthetic orchid Himantoglossum adriaticum. - Plant Ecology and Evolution 146(2): 145-152.

[37] R. Eszéki, E., Szendrák, E. (1992): Experiments to propagate native hardy orchids (Orchidaceae) in the ELTE Botanical Garden. - 20th Cong. Hung. Biol. Soc. 1992, Kecskemét.

[38] Ramsay, R. R., Sivasithamparam, K., Dixon, K. W. (1986): Patterns of infection and endophytes associated with Western Australian orchids. - Lindleyana 1: 203-214.

[39] Rasmussen, H. N. (1995): Terrestrial orchids, from seed to mycotrophic plant. Cambridge University Press, Cambridge.

[40] Rasmussen, H. N. (2002): Recent developments in the study of orchid mycorrhiza. Plant and Soil 244: 149-163.

[41] Rasmussen, H. N., Whigham, D. F. (1993): Seed ecology of dust seeds in situ: A new study technique and its application in terrestrial ecology. - American Journal of Botany 80: $1374-1378$

[42] Rasmussen, H. N., Dixon, K. W., Jersáková, J., Těšitelová, T. (2015): Germination and seedling establishment in orchids: a complex of requirements. - Annals of Botany 116(3): 391-402.

[43] Richter, W. (1982): Orchideen: Pflegen, Vermehren, Züchten. - Neumann, Radebeul.

[44] Roberts, D. L. (2003): Pollination biology: the role of sexual reproduction in orchid conservation. - In: Dixon, K. W., Kell, S. P., Barrett, R. L., Cribb, P. J. (eds.) Orchid conservation. Natural History Publications, Kota Kinabalu.

[45] Rybka, V., Rybková, R., Pohlová, R. (2005): Plants of the Natura 2000 Network in the Czech Republic. - Sagittaria, Praha.

[46] Shirokov, A. I., Syrova, V. V., Kryukov, L. A., Shtarkman, N. N., Shestakova, A. A. (2016): Reintroduction of Dactylorhiza incarnata into the natural habitats of the European Russia. - Applied Ecology and Environmental Research 15(1): 445-455.

[47] Sosa, V., Platas, T. (1998): Extinction and persistence of rare orchids in Veracruz, Mexico. - Conservation Biology 12: 451-455.

[48] Stoutamire, W. P. (1983): Wasp-pollinated species of Caladenia (Orchidaceae) in southwestern Australia. - Australian Journal of Botany 31: 383-394. 
[49] Sulyok, J., Vidéki, R., Molnár V., A. (1998): Data for the knowledge of Himantoglossum species in Hungary (in Hungarian) - Kitaibelia 3(2): 223-229.

[50] Swarts, N. D., Dixon, K. W. (2009): Terrestrial orchid conservation in the age of extinction. - Annals of Botany 104: 543-556.

[51] Szabó, I. (1987): A Keszthelyi-hegység növényvilágának kutatása. [Research of the flora of the Keszthely Hills] (in Hungarian). - A Bakony Természettudományi Múzeum Közleményei 6: 77-98.

[52] Teschner, W. (1980): Sippendifferenzierung und Bestäubung bei Himantoglossum Koch. - Jahresberichte des Naturwissenschaftlichen Vereins Wuppertal 33: 104-116.

[53] Van der Kinderen, G. (1995): A method for the study of field germinated seeds of terrestrial orchids. - Lindleyana 10: 68-73.

[54] Van Waes, J. M., Debergh, P. C. (1986a). Adaptation of the tetrazolium method for testing the seed viability, and scanning electron microscopy study of some Western European orchids. - Physiology of Plants 66: 435-442.

[55] Van Waes, J. M., Debergh, P. C. (1986b). In vitro germination of some Western European orchids. - Physiology of Plants 67: 253-261.

[56] Vöth, W. (1990): Effective und potentielle Bestäuber von Himantoglossum. Mittelungblatt AHO Baden-Württemberg 22: 337-351.

[57] Warcup, J. H. (1971): Specificity of mycorrhizal association in some Australian terrestrial orchids. - New Phytologist 70: 41-46.

[58] Warcup, J. H. (1981): The mycorrhizal relationships of Australian orchids. - New Phytologist 87: 371-381.

[59] Woolcock, C. E., Woolcock, D. T. (1984): Australian terrestrial orchids. - Melbourne: Thomas Nelson.

[60] Zelmer, C. D., Cuthbertson, L., Currah, R. S. (1996): Fungi associated with terrestrial orchid mycorrhizas, seeds and protocorms. - Mycoscience 37: 439-446.

[61] Website of MetNet: Climatic data for making the Walter-Lieth diagrams. https://www.metnet.hu/napi-adatok?sub=2\&order=1. 